\title{
Evaluation of Sensory Quality and Nutritional Value of Fish Cakes (Perkedel) Made by Tuna Fish (Euthynnus affinis) and Milk Fish (Chanos chanos)
}

\author{
Erven Era Prastica, Endang Dewi Masithah", and Kustiawan Tri Pursetyo \\ Department of Marine Science, Faculty of Fisheries and Marine, Universitas Airlangga, Surabaya, East Java, Indonesia \\ *Corresponding author's Email: endang-d-m@fpk.unair.ac.id; (DORCiD: 0000-0001-9932-1039
}

\begin{abstract}
Fish Cakes (Perkedel) is Indonesian fried patties, most commonly made from mashed potatoes mix with beef or chicken. This research was conducted to determine the sensory quality and the best nutritional value of the cakes which are composed of tuna fish and milkfish. The study used an experimental method with the main parameters of sensory quality (organoleptic test) and nutritional value (proximate analysis) in seven different cake treatments. The results showed that the composition of tuna fish and milkfish of fish cakes had a very significant effect on the color and aroma aspects, while the texture and taste aspects were not significantly different among the treatments. The findings indicated that the composition of tuna fish and milkfish only affected color and aroma. The best formulation of the fish cake was on Perkedel 7 (P7) which has a sufficiently good organoleptic color, aroma, texture, and taste with higher nutrient content, compared with other treatments. The nutritional content of P7 was Recommended Dietary Allowance (RDA) protein of $28.77 \%$, RDA fat of $0.68 \%$, and RDA carbohydrate of $7.41 \%$. Moreover, it also produced energy of $162 \mathrm{kcal} / 100 \mathrm{~g}$. In conclusion, fish cake with great sensory quality and nutritional values was obtained with $45 \mathrm{~g}$ of tuna fish and $15 \mathrm{~g}$ of milkfish. The P7 formulation is a combination of $45 \mathrm{~g}$ of tuna fish and $15 \mathrm{~g}$ of milkfish. The RDA obtained from fish cakes in the best treatment Perkedel 7 (P7) was $28.77 \%$ for RDA protein, $0.68 \%$ for fat, and $7.41 \%$ for carbohydrates. The investigated fish cakes provide energy of $162 \mathrm{kcal} / 100 \mathrm{~g}$ at an affordable price.
\end{abstract}

Keywords: Milk fish, Organoleptic test, Proximate analysis, RDA nutrition, Tuna fish

\section{INTRODUCTION}

Fish Cakes (perkedel) are a typical food product that is quite favored by people in some countries (Archana et al., 2016). Many cakes products experience diversification with the addition of chicken, beef, shrimp (Adesola Olayinka et al., 2009), other types of fish meat, and some processed animal protein. Moreover, the vegetable protein used is not only sourced from potatoes but sometimes also processed mushrooms and anchovies ingredients (Hwang et al., 2013). In addition, cakes are also consumed as popular daily food (Archana et al., 2016; Rahma et al., 2019).

For middle and lower-middle groups, this matter definitely cannot be reached, therefore the solution is to use fish meat to make delicious and nutritious cakes at more affordable and economical prices (Islam et al., 2018; Mottaleb et al., 2018). Currently, the use of surimi is an alternative to making burgers, ham, and other food products. It is because the price of surimi is cheaper than shrimp and beef and it has an appropriate nutritional value (Bashir et al., 2017).

Some fish species that can be used as fish cakes are tuna fish and milkfish because they are found easily in Indonesia. The reason why tuna fish and milkfish become selected ingredients for making fish cakes is because of the relatively high production volume. Tuna fish had a production volume of 230.580 tons in 2011 while milkfish had 631.125 tons in 2014. Tuna fish and milkfish have high protein and low-fat content. Most of the ingredients are essential and non-essential amino acids (Vasava et al., 2018), omega 3 (Rani et al., 2016), and unsaturated fats (Bayaga and Deveza, 2005). Milkfish has the highest protein content of $22.7 \%$ and the lowest fat content of $2 \%$ (Magondu et al., 2016) while the high protein and low-fat content of tuna fish are around $25 \%$ and $1.25 \%$, respectively (Rani et al., 2016).

Milkfish is a kind of fish that mostly live in tropical freshwaters (Darmawan et al., 2019). Milkfish has a distinctive color, smell, taste, and texture (Villagonzalo, 2008; Hakim et al., 2019). Therefore, the composition of tuna fish and milkfish can produce fish cakes which have good sensory quality.

The experiments are carried out to increase the quality of fish cakes produced, either sensory quality or nutritional value. Thus, this research was performed to obtain the best sensory quality and nutritional value from the cakes which are composed of tuna fish and milkfish. 
The experimental design was a combination of a completely randomized research design, by a single factor experiment in the form of different formulations of tuna fish and milkfish composition. Tuna fish and milkfish would be combined to obtain the best quality and nutritional values (Robinson et al., 2009). The performed method included seven treatments and four repetitions with the calculation of $t$ (n-1)> 15 (Kusuriningrum, 2008).

The independent variables used were tuna fish and milkfish, while the dependent variable was the sensory quality (color, aroma, texture, and taste) and physicochemical characteristics (water content, ash content, carbohydrate content, fat content, and protein content) of fish cakes. Moreover, control variables in this study were material size, making process, seasoning concentration, setting and cooking temperature, and heating time.

The first test was carried out using quantitative and qualitative parameters. The main test parameters were organoleptic, water content, ash content, protein content, fat content, and carbohydrate content. The supporting test parameters were the yield of raw materials and products, as well as analysis of Total Volatile Base (TVB) and histamine. Tests of organoleptic data from research results were processed using Kruskal-Wallis analysis. The Kruskal-Wallis analysis was used to determine the treatment rating for various product samples (Elamir, 2015).

Tuna fish and milkfish are common types of fish that can be obtained from traditional markets, among them in Surabaya City markets. Subsequently, batter is made by adding a high amount of water and low viscosity to Japanese breadcrumbs (Owens, 2001).

Table 1 presents the formulation of ingredients for making cakes with seven treatments using ingredients and dough in the same amount and composition. Tuna fish and milkfish are used as the meat that is separated from the thorns and skin through the steaming process. The fish meat that has been separated from the thorns and skin then made a composition of tuna fish: milkfish with ratios of 1:0, 0:1, 1:1, 1:2, 2:1, 1:3, and 3:1 as in Table 1. Then, the composition of fish meat is crushed manually so the meat will not be too crumbled (Fuchs et al., 2013)

Table 1. Ingredients formulation for Making Cakes (Perkedel)

\begin{tabular}{|c|c|c|c|c|c|c|c|}
\hline Ingredients (g) & P1 & $\mathbf{P 2}$ & $\mathbf{P 3}$ & P4 & P5 & P6 & P7 \\
\hline Coconut (g) & 20 & 20 & 20 & 20 & 20 & 20 & 20 \\
\hline Salt (g) & 3 & 3 & 3 & 3 & 3 & 3 & 3 \\
\hline Sugar (g) & 7 & 7 & 7 & 7 & 7 & 7 & 7 \\
\hline Pepper (g) & 2 & 2 & 2 & 2 & 2 & 2 & 2 \\
\hline Shallot (g) & 4 & 4 & 4 & 4 & 4 & 4 & 4 \\
\hline Garlic (g) & 4 & 4 & 4 & 4 & 4 & 4 & 4 \\
\hline Tuna Fish (g) & $60(1)$ & $0(0)$ & $30(1)$ & $20(1)$ & $40(2)$ & $15(1)$ & $45(3)$ \\
\hline Milkfish (g) & $0(0)$ & $60(1)$ & $30(1)$ & $40(2)$ & $20(1)$ & $45(3)$ & $15(1)$ \\
\hline
\end{tabular}

\section{RESULTS}

All treatments produce various organoleptic. One treatment and another will be compared according to the standard score that has been made. The other observations are also carried out on products that have the highest and lowest scores.

The results of the analysis of various colors and aromas in Table 2 showed that there were very significant different interactions $(p<0.01)$ between the concentration treatment of tuna fish and milkfish with the color of fish cakes. The color on P2 had the highest organoleptic score, while the color on P1 had the lowest organoleptic score. For various aroma formulas, P1 had the highest score, but P1 was not significantly different from P7. It was probably due to the content of tuna fish that was almost $100 \%$.

The results of the variance analysis showed that there were no significant differences between the concentration treatment of tuna fish and milkfish on the texture and taste of fish cakes produced ( $p>0.05)$. Organoleptic texture scores given by panelists ranged from 3.6 to 3.9 or slightly dense and fibrous. Formulations with the best texture were in P1 and P7. Meanwhile, the organoleptic test score for taste ranged from 3.0 to 3.4 (quite ideal). The best treatment for flavor formulations was on $\mathrm{P} 7$.

\section{Results of proximate, recommended dietary allowance, and energy}

Proximate analysis is performed to determine the nutritional content of fish cake products. Proximate analysis that is examined includes water, ash, protein, fat, and carbohydrate content. Fish cakes are prepared with several basic ingredients and each of which has a different nutritional contribution. Coconut contains $1 \%$ protein, $0.9 \%$ fats, and $14 \%$ carbohydrates in 20 grams. Pepper contains $11.5 \%$ proteins, $6.8 \%$ fats, and $64.4 \%$ carbohydrates in 2 g. Shallot contains $1.5 \%$ protein, $0.3 \%$ fat, and $0.2 \%$ carbohydrates in 3 grams. Garlic contains $4.5 \%$ proteins, $0.2 \%$ fats, and $23.1 \%$ carbohydrates in 2 grams. Eggs contain $12.8 \%$ proteins, $11.5 \%$ fats, and $0.7 \%$ carbohydrates in 3 grams (RehaultGodbert et al., 2019). 
After accumulating with a proximate analysis, all the ingredients that are mixed with a comparison of multivariants tuna fish and milkfish produce different contents which are presented in Table 3. The results of the proximate analysis in 100 grams produce different contents. The highest water content was observed in treatment 5 , and the lowest water content was in treatment 2 . The highest protein content occurred in treatment 7 , and the lowest protein content was in treatment 4 . The highest fat content was reported in treatment 6 , and the lowest fat content was in treatment 7 . The highest carbohydrate content occurred at treatment 4 , and the lowest carbohydrate content was estimated in treatment 1.

Proximate analysis in each formulation was carried out to determine the nutritional content of each on the results of fish cakes. By this proximate analysis, the RDA of different nutritional values was eventually obtained. Based on Table 4, the best treatment was at P7 for it had the highest protein RDA value and the lowest fat RDA value. The calorific value produced by fish cakes in the P7 formulation was every 100 grams contains $162 \mathrm{kcal}$. This value was obtained because every 1 gr of carbohydrate contained 4000 calories, while 1 gram of fat contained 9000 calories, and 1 gr of protein had 4 calories (Lagergren et al., 2013).

Table 2. Organoleptic test results on treatments

\begin{tabular}{lcccc}
\hline Organoleptic Test & Color & Aroma & Texture & Taste \\
\hline Treatment 1 & 3.81 & 3.77 & & 3.87 \\
Treatment 2 & 4.71 & 3.43 & 3.66 & 3.31 \\
Treatment 3 & 4.38 & 3.43 & 3.66 & 3.17 \\
Treatment 4 & 4.48 & 3.31 & 3.66 & 3.16 \\
Treatment 5 & 4.27 & 3.49 & 3.66 & 3.08 \\
Treatment 6 & 4.57 & 3.52 & 3.63 & 3.18 \\
Treatment 7 & 4.22 & 3.53 & 3.78 & 3.34 \\
\hline
\end{tabular}

Table 3. Proximate analysis results $(\%)$

\begin{tabular}{|c|c|c|c|c|c|}
\hline Proximate values & Water content & Ash content & Protein content & $\begin{array}{c}\text { Fat } \\
\text { content }\end{array}$ & $\begin{array}{c}\text { Carbohydrate } \\
\text { content }\end{array}$ \\
\hline Treatment 1 & 55.39 & 10.81 & 15.59 & 3.34 & 14.87 \\
\hline Treatment 2 & 54.37 & 7.48 & 13.95 & 3.13 & 21.07 \\
\hline Treatment 3 & 54.89 & 9.58 & 14.24 & 1.15 & 20.14 \\
\hline Treatment 4 & 54.88 & 5.24 & 8.55 & 2.10 & 29.23 \\
\hline Treatment 5 & 55.60 & 4.09 & 15.17 & 2.30 & 22.84 \\
\hline Treatment 6 & 55.47 & 4.98 & 14.88 & 3.38 & 21.29 \\
\hline Treatment 7 & 55.17 & 4.92 & 17.26 & 0.42 & 22.23 \\
\hline
\end{tabular}

Table 4. Recommended dietary allowance value of fish cakes (Perkedel)

\begin{tabular}{lccc}
\hline Recommended dietary allowance & Protein content* & $\begin{array}{c}\text { Fat } \\
\text { content* }\end{array}$ & $\begin{array}{c}\text { Carbohydrate } \\
\text { content* }\end{array}$ \\
\hline Treatment 1 & 25.98 & 5.39 & 4.96 \\
Treatment 2 & 23.25 & 5.05 & 7.02 \\
Treatment 3 & 23.37 & 1.85 & 6.71 \\
Treatment 4 & 14.25 & 3.39 & 9.74 \\
Treatment 5 & 25.28 & 3.71 & 7.61 \\
Treatment 6 & 24.80 & 5.45 & 7.10 \\
Treatment 7 & 28.77 & 0.68 & 7.41 \\
\hline
\end{tabular}

*: Refers to the percent of dry matter

\section{DISCUSSION}

Organoleptic testing performed is not just to get the impression of likes or dislikes of samples, but to determine whether the product is accepted by the panelist. The organoleptic test is a test performed based on the sensing process (Yi et al., 2016). The purpose of the organoleptic test is to find the differences between samples (one another), so as to obtain the best product results (Ana et al., 2017; Widyastuti et al., 2019). It is also performed to evaluate food, especially organoleptic properties of pastry products including aroma, taste, and texture.

The results of the data analysis showed that there were significant differences between treatments on color and aroma parameters, while texture and taste parameters were not significantly different. The best color of the inside of fish cakes was observed in treatment P2since the fish composition in the fish cakes of P2 formulation was 100\% milkfish so that the white structure was formed. Moreover, milkfish has a color attribute distribution of 44.90 (Villagonzalo, 2008). In a study conducted by Chen and Chow-Jen (2001), it was found that milkfish had a low myoglobin content so that when the warming or denaturation of globin was carried out, the color of the product would be even brighter. 
The aroma parameter most favored by panelists is the P1 Treatment since P1 had $100 \%$ tuna fish (60 g). The score from the organoleptic test results for flavors was ranged from 3 to 3.4 (quite ideal). The formulation with the highest taste preference score is in the P7 treatment. It is probably due to a balanced mix of flavors.

Based on the proximate results in Table 3, the average water content produced by fish cakes in seven treatments was within the range of 54.37-55.60\%. These levels can still be accepted by Indonesian National Standard (SNI) on products that have similar characteristics to fish cakes, namely nuggets. Meanwhile, the average protein content produced by fish cakes in seven formulations ranged from 8.55-17.26\%. The lowest protein content is found in $\mathrm{P} 4$ formulation so that P4 is not included in the nutrient content of SNI 01-6683-2002 which states that the protein content must be at least $12 \%$. Furthermore, P4 also does not meet the requirements for carbohydrate levels because it exceeds $25 \%$.

Protein is needed by the body for the growth, development, maintenance, and repair of damaged body tissue. Water content and fat content in fish are quite fluctuating (Pal et al., 2018). The fat found in fish cakes is mostly a type of unsaturated fat that is good for health (Bayaga and Deveza, 2005). The carbohydrate content in fish cakes mainly comes from tapioca flour and bread flour with its carbohydrate content per 100 grams holds more than $75 \%$ or around 26 grams (Montes et al., 2015).

\section{CONCLUSION}

The best fish cakes with the highest sensory quality and nutritional value were observed in the P7 treatment. It had higher protein content than other treatments and a low-fat content (in accordance with SNI 01-6683-2002). The P7 treatment was a combination of $45 \mathrm{~g}$ of tuna fish and $15 \mathrm{~g}$ of milkfish. The Recommended Dietary Allowance (RDA) obtained from fish cakes was at its best in P7 treatment with $28.77 \%$ RDA protein, $0.68 \%$ fat, and $7.41 \%$ carbohydrates. The investigated fish cakes provide energy of $162 \mathrm{kcal} / 100 \mathrm{~g}$. For future studies, treatment with a high combination of $45 \mathrm{~g}$ of tuna fish and $15 \mathrm{~g}$ of milkfish is suggested.

\section{DECLARATIONS}

\section{Authors' contributions}

All authors approved the final draft of the manuscript for publication. Ethical issues (including plagiarism, consent to publish, misconduct, data fabrication and/or falsification, double publication and/or submission, and redundancy) have been checked by the authors.

\section{Competing interests}

All authors declared no conflict of interests.

\section{REFERENCES}

Adesola Olayinka O, Tope AA, Patricia O, and Akande Gbola R (2009). The nutritional composition, sensory evaluation and microbiological studies of fish cake made from shrimp bycatch. African Journal of Food Science, 3(7): 177-183. Available at: https://www.internationalscholarsjournals.org/print.php?article=the-nutritional-composition-sensory

Ana A, Subekti S, Hamidah S, and Komariah K (2017). Organoleptic test patisserie product based on consumer preference. IOP Conference Series Materials Science and Engineering, 180(1): 012294. DOI: https://www.doi.org/10.1088/1757-899X/180/1/012294

Archana G, Azhagu Saravana Babu P, Sudharsan K, Sabina K, Palpandi Raja R, Sivarajan M, and Sukumar M (2016). Evaluation of fat uptake of polysaccharide coatings on deep-fat fried potato chips by confocal laser scanning microscopy. International Journal of Food Properties, 19: 1583-1592. DOI: https://www.doi.org/10.1080/10942912.2015.1065426.

Bashir KMI, Kim JS, An JH, Sohn JH, and Choi JS (2017). Natural food additives and preservatives for fish-paste products: A Review of the past, present, and future states of research. Journal of Food Quality, Article ID 9675469. DOI: https://www.doi.org/10.1155/2017/9675469.

Bayaga CLT, and Deveza Gf (2005). Milkfish (Chanos chanos Forskaal) consumption in the philippines and the docosahexaenoic acid level of the cooked fish. Food Science and Technology Research, 11(1): 127-133. DOI: https://www.doi.org/10.3136/fstr.11.127

Chen W, and Chow-Jen C (2001). Studies on the physicochemical properties of milkfish myoglobin. Journal of food biochemistry, 25(2): 157-174. DOI: https://www.doi.org/10.1111/j.1745-4514.2001.tb00731.x.

Darmawan D, Sulmartiwi L, and Abdillah AA (2019). The effect of kappa-carrageenan fortification on the physicochemical and organoleptic properties of milkfish galantin. IOP Conference Series: Earth and Environmental Science, 236: 012116. DOI: https://www.doi.org/10.1088/1755-1315/236/1/012116.

Elamir EAH (2015). Kruskal-Wallis test: A graphical way. International Journal of Statistics and Applications, 5(3): 113-119. DOI: https://www.doi.org/10.5923/j.statistics.20150503.03.

Fuchs RHB, Ribeiro RP, Matsushita M, Tanamati AAC, Bona E, and de Souza AHP (2013). Enhancement of the nutritional status of Nile tilapia (Oreochromis niloticus) croquettes by adding flaxseed flour. LWT-Food Science and Technology, 54(2): 440-446. DOI: https://www.doi.org/10.1016/j.lwt.2013.07.004.

Hakim DA, Tjahjaningsih W, and Sudarno (2019). Antibacterial activity of honey in preserving high-pressure cooked milkfish stored at room temperature. IOP Conference Series: Earth and Environmental Science, 236: 012079. DOI: https://www.doi.org/10.1088/1755$\underline{1315 / 236 / 1 / 012079}$.

Hwang HJ, Choi SY, and Lee SC (2013). Preparation and quality analysis of sodium-reduced fried fish cakes. Preventive Nutrition and Food Science, 
Islam MJ, Sayeed MA, Akhtar S, Hossain MS, and Liza AA (2018). Consumers profile analysis towards chicken, beef, mutton, fish and egg consumption in Bangladesh. British Food Journal, 120: 2818-2831. DOI: https://www.doi.org/10.1108/BFJ-03-2018-0191.

Kusuriningrum (2008). Perancangan Percobaan. Pusat Penerbitan dan Percetakan Unair (AUP), Surabaya. Hal, 11(1): 179-190. Available at: https://slideplayer.info/amp/12562646/

Lagergren K, Lindam A, and Lagergren J (2013). Dietary proportions of carbohydrates, fat, and protein and risk of oesophageal cancer by histological type. PLOS ONE, 8(1): e54913. DOI: https://www.doi.org/10.1371/journal.pone.0054913.

Magondu EW, Mokaya M, Ototo A, and Nyamora J (2016). Growth performance of milkfish (Chanos chanos Forsskal) fed on formulated and nonformulated diets made from locally available ingredients in South Coast region, Kenya. International Journal of Fisheries and Aquatic Studies, 4(1): 288-293. Available at: https://www.fisheriesjournal.com/archives/?year=2016\&vol=4\&issue=1\&part=D\&ArticleId=640.

Montes SDS, Rodrigues LM, Cardoso RDCV, Camilloto GP, and Cruz RS (2015). Tapioca and rice flour cookies: technological, Food Science and Technology, 39(5): 514-522. DOI: https://www.doi.org/10.1590/S1413-70542015000500010.

Mottaleb KA, Rahut DB, Kruseman G, and Erenstein O (2018). Evolving food consumption patterns of rural and urban hou seholds in developing countries: A Bangladesh case. British Food Journal, 120: 392-408. Available at: https://www.emeraldinsight.com/doi/abs/10.1108/BFJ-122016-0620.

Owens CM (2001). Coated poultry products. Poultry Meat Processing, pp. 227-242. Available at: https://www.routledge.com/Poultry-MeatProcessing/Owens/p/book/9781420091892

Pal J, Shukla BN, Maurya AK, Verma HO, Pandey G, and Amitha (2018). A review on role of fish in human nutrition with special emphasis to essential fatty acid. International Journal of Fisheries and Aquatic Studies, 6(2): 427-430. Available at: https://www.fisheriesjournal.com/archives/2018/vol6issue2/PartF/6-2-50-593.pdf.

Rahma A, Abdillah AA, and Saputra E (2019). The Use of rajungan (Portunus Pelagicus) shells as flour in wet noodles ingredient. IOP Conference Series: Earth and Environmental Science, 236: 012124. DOI: https://www.doi.org/10.1088/1755-1315/236/1/012124.

Rani PSCHPD, Kumar PPNV, Rao KR, and Shameem U (2016). Seasonal variation of proximate composition of tuna fishes from Visakhapatnam fishing harbor, East coast of India. International Journal of Fisheries and Aquatic Studies, 4(6): 308-313. Available at: https://www.fisheriesjournal.com/archives/2016/vol4issue6/PartE/4-6-33-143.pdf.

Rehault-Godbert S, Guyot N, and Nys Y (2019). The golden egg: Nutritional value, bioactivities, and emerging benefits for human health. Nutrients, 11(3): 684-689. DOI: https://www.doi.org/10.3390/nu11030684

Robinson TJ, Brenneman WA, and Myers WR (2009). An intuitive graphical approach to understanding the split-plot experiment. Journal of Statistics Education, 17: 1-15. DOI: https://doi.org/10.1080/10691898.2009.11889505.

Vasava R, Shrivastava V, Mahavadiya D, Sapra D, and Vadher D (2018). Nutritional and feeding reuirement of milk fish (Chanos chanos). International journal of pure and applied bioscience, 6(2): 1210-1215. DOI: http://www.dx.doi.org/10.18782/2320-7051.6463.

Villagonzalo JM (2008). Acceptability of milkfish (Chanos-Chanos) sausage: techno-guide for instruction and extension activities. Tropical Technology Journal, 11: 1-6. Available at: http://jatm.ctu.edu.ph/index.php/ttj/article/view/62/84.

Widyastuti A, Abdillah A, and Sulmartiwi L (2019). The Potential of lindur fruit flour (Bruguiera Gymnorrhiza) in reducing oil absorption of milkfish nugget during the deep frying process. IOP Conference Series Earth and Environmental Science, 236: 012125. DOI: https://www.doi.org/10.1088/1755-1315/236/1/012125

Yi J, Zhou L, Bi J, Chen Q, Liu X, and Wu X (2016). Influence of pre-drying treatments on physicochemical and organoleptic properties of explosion puff dried jackfruit chips. Journal of Food Science and Technology, 53(2): 1120-1129. DOI: https://www.doi.org/10.1007/s13197-015-2127-2 